\title{
Prevalence estimate of intimate partner violence in Jordan
}

C.J. Clark, ${ }^{1}$ D.E. Bloom, ${ }^{1}$ A.G. Hill ${ }^{1}$ and J.G. Silverman ${ }^{2}$

$$
\begin{aligned}
& \text { تقدير انتشار العنف مع القرين الحميم في الأردن }
\end{aligned}
$$

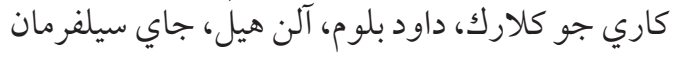

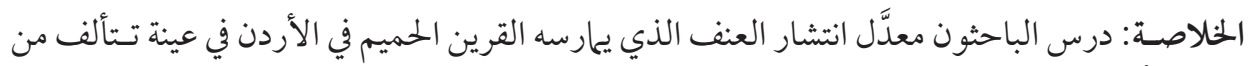

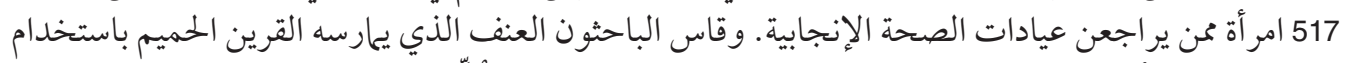

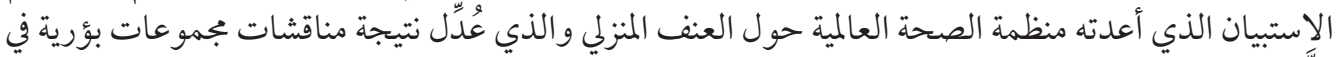

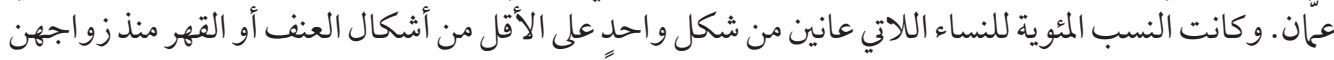

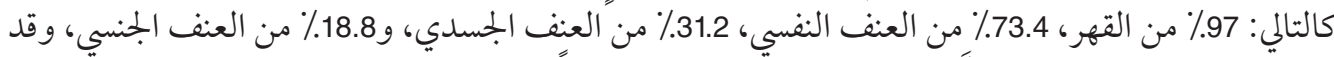

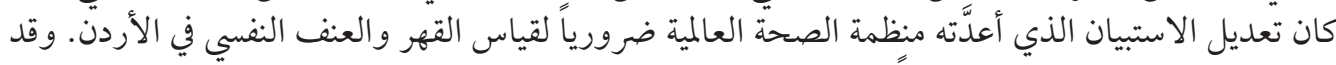

$$
\begin{aligned}
& \text { يكون القيام بتعديلات مماثلة ضرورياً عند إجراء البحنة البحت العالية في الإقليم. }
\end{aligned}
$$

ABSTRACT This study examined the prevalence of intimate partner violence in Jordan among a sample of 517 reproductive health clinic attendees. Intimate partner violence was measured using the World Health Organization's domestic violence questionnaire which was modified by the results of focus group discussions conducted in Amman. The percentages of women experiencing at least 1 form of control or violence since marriage were: control, 97.2\%; psychological violence, 73.4\%; physical violence, $31.2 \%$; and sexual violence, $18.8 \%$. Modifications of the WHO questionnaire were needed to measure control and psychological violence in Jordan. Similar modifications might be required when conducting research in the Region.

\section{Estimation de la prévalence de la violence exercée par le partenaire intime en Jordanie}

RÉSUMÉ Cette étude portait sur la prévalence de la violence exercée par le partenaire intime en Jordanie sur un échantillon de 517 personnes fréquentant des centres de santé génésique. Cette violence a été mesurée au moyen du questionnaire sur la violence familiale de l'Organisation mondiale de la santé, qui a été modifié suite à des réunions de groupe de discussion tenues à Amman. Les pourcentages de femmes ayant subi au moins une forme de comportement autoritaire ou de violence depuis le mariage se décomposaient comme suit : comportement autoritaire, 97,2 \% ; violence psychologique, $73,4 \%$; violence physique, $31,2 \%$; et violence sexuelle, 18,8 \%. Les modifications apportées au questionnaire de l'OMS étaient nécessaires pour mesurer les comportements autoritaires et la violence psychologique en Jordanie. II sera peut-être nécessaire de procéder à des modifications similaires aux fins de la réalisation de travaux de recherche dans la région.

${ }^{1}$ Department of Global Health and Population; ${ }^{2}$ Department of Society, Human Development and Health, Harvard School of Public Health, Boston, Massachusetts, United States of America (Correspondence to C.J. Clark: carijoclark@post.harvard.edu).

Received: 06/03/07; accepted: 16/04/07

المجلة الصحية لشرق المتوسط، منظمة الصحة العالمية، المجلد الخامس عشر، العدد ع، 9 •. ب 


\section{Introduction}

Intimate partner violence is a global public health crisis because of its high prevalence $[1,2]$ and its association with deleterious physical, mental, and reproductive health outcomes [2-6]. Efforts to examine the prevalence, consequences, and causes of intimate partner violence cross-culturally have increased over the past decade. Examples include the World Health Organization (WHO) multi-country study on women's health and domestic violence against women, the WorldSAFE initiative, and implementation of domestic violence modules in some Demographic and Health Surveys (DHS) $[1,7,8]$. Despite these international initiatives, Jordan still lacks methodologically sound data on intimate partner violence, particularly an estimate of the prevalence.

Studies from other Middle Eastern countries indicate a high prevalence of intimate partner violence in the region. According to a nationally representative sample of Egyptian women, at least 1 in 3 was subjected to physical violence following marriage, and these acts were perpetrated almost exclusively by their husbands [9]. In 2 different nationally representative samples of Palestinian women in the West Bank and Gaza Strip, over half the respondents reported experiencing at least 1 act of physical violence from their husbands in the 12 months preceding the survey [10]. Among primary health care clinic attendees in Aleppo, Syria, $23.1 \%$ of respondents reported experiencing physical violence at least 3 times in the year preceding the survey, most frequently by their husbands [11].

These figures demonstrate high prevalence estimates of intimate partner violence in the region, but they cannot be automatically applied to Jordan as each country has its own set of social, cultural, political and economic circumstances. Therefore, Jordan needs a context-specific estimate. This need must be weighed against the benefits of standardization and comparability. A standardized estimate, however, does not necessarily translate into a valid measurement of the prevalence of intimate partner violence unless it captures the most commonly occurring violent experiences [12].

The gap between a comparable and a valid measurement of intimate partner violence can be bridged by the inclusion of qualitative research to identify the types of violence that women experience. Qualitative research can illuminate forms of abuse that may not be included in standardized questionnaires [13]. It also can capture meaning and context [14], providing a basis from which to judge the applicability of standardized questionnaires. A combined quantitative and qualitative approach balances concomitant goals of standardization and validity. The present study used a combined approach to estimate the prevalence of intimate partner violence in Jordan.

\section{Methods}

\section{Overview}

Focus group discussions conducted with women in Amman identified the types of violence that women experience within the family. This information was used to modify the WHO domestic violence questionnaire [1] to better measure women's experiences of violence in Jordan. The revised questionnaire was then administered to clients attending selected clinics of the Jordanian Association for Family Planning and Protection (JAFPP) throughout the country to estimate the prevalence of intimate partner violence.

The institutional review board at Harvard School of Public Health and faculty mem-

المجلة الصحية لشرق المتوسط، منظمة الصحة العالمية، المجلد الخنامس عشر، العدد ع، 9 +. 
bers of the University of Jordan approved this study.

\section{Focus group discussions \\ Sample}

To ascertain the types of violence that Jordanian women experience, 18 focus group discussions, including 1 pilot test, were conducted with women in and around Amman. The groups were organized on the basis of marital status (never-married, currently married, divorced, and widowed) by the study's partner organizations. These organizations served a varied clientele. The Sisterhood is Global Institute provided access to women receiving legal, social and psychological counselling for domestic violence. The Young Women's Christian Association provided access to young secretarial students and residents of a refugee camp who were participating in their programmes. The United Nations Relief and Works Agency for Palestinian Refugees in the Middle East provided access to women dwelling in refugee camps or other women who participated in activities geared toward women. The University of Jordan Faculty of Nursing and Community Service Office provided access to faculty and students. Finally, the Single Parents' Club provided access to women who were either divorced or widowed. Overall, the women who participated via these organizations were diverse in terms of age, number of children and years of education (Table 1).

\section{Process}

Each discussion, which lasted between 1.5 and 2 hours, was held in facilities provided by the partner organizations and was conducted by a professional focus group moderator and a notetaker/translator. After obtaining oral consent from the participants, the moderator facilitated the sessions using a guide that covered the following content areas: definition of domestic violence, causes and consequences of domestic violence and assistance for victims. The same questions were asked of each group in a directive manner [15], which produced a structured discussion [16]. However, the moderator adjusted her level of control to ensure that spontaneity and group interaction were not sacrificed for standardization.

To protect the participants' identities, number badges were substituted for name badges for note-taking purposes. Participants were instructed not to mention personal details or names. Participants were asked to respect the privacy of the group by not mentioning the content of the discussion with anyone outside the group.

\section{Survey instrument development}

All transcripts were translated from Arabic to English. Selected community members and the notetaker/translator were asked to clarify the meaning of some colloquial terms to validate the primary investigator's interpretation. Categories and sub-categories of types of violence were then coded using an open coding methodology [17] and mapping. This process was informed by, but not restricted to, the study's working definition of intimate partner violence as "any behaviour (including 'control') within an intimate relationship that causes physical, psychological or sexual harm to those in the relationship" [2].

The participants' perceptions and experiences of violence that were categorized as physical, psychological, sexual or control were compared to the behaviour-specific questions on the WHO's Women's Health and Domestic Violence Against Women questionnaire [1]. The questionnaire items were considered to be valid representations of women's experiences if they captured the events that the participants described within each of these categories. For physi- 
Table 1 Demographic characteristics of the focus group discussion participants

\begin{tabular}{|c|c|c|c|c|}
\hline $\begin{array}{l}\text { Marital status and recruiting } \\
\text { organization (location) }\end{array}$ & $\begin{array}{c}\text { No. of } \\
\text { participants }\end{array}$ & $\begin{array}{l}\text { Mean age } \\
\text { (years) }\end{array}$ & $\begin{array}{l}\text { Mean no. of } \\
\text { children }\end{array}$ & $\begin{array}{l}\text { Mean years } \\
\text { of education }\end{array}$ \\
\hline \multicolumn{5}{|l|}{ Pilot study } \\
\hline UNRWA (AI Wihdat refugee camp) ${ }^{a}$ & NA & NA & NA & NA \\
\hline \multicolumn{5}{|l|}{ Never married } \\
\hline UJ (community service office) & 6 & 19.7 & 0.0 & 14.8 \\
\hline UNRWA (AI Wihdat refugee camp)a & 6 & 20.7 & 0.0 & 12.7 \\
\hline UNRWA (Jabal Hussein refugee camp) & 8 & 20.8 & 0.0 & 12.6 \\
\hline YWCA (headquarters) & 9 & 19.0 & 0.0 & 12.0 \\
\hline \multicolumn{5}{|l|}{ Currently married } \\
\hline SIGI (headquarters) & 9 & 36.4 & 4.9 & 11.7 \\
\hline UJ (faculty of nursing) & 6 & 45.3 & 3.7 & 18.0 \\
\hline UNRWA (AI Wihdat refugee camp)a & 6 & 34.8 & 6.3 & 10.3 \\
\hline UNRWA (AI Wihdat refugee camp)a & 6 & NA & NA & NA \\
\hline UNRWA (Jabal Hussein refugee camp) & 6 & 29.8 & 3.2 & 12.2 \\
\hline YWCA (headquarters) & 6 & 33.5 & 1.5 & 14.3 \\
\hline \multicolumn{5}{|l|}{ Divorced } \\
\hline SPC (member's house) & 4 & 43.3 & 1.5 & 15.0 \\
\hline SIGI (headquarters) & 4 & 37.3 & 3.3 & 12.0 \\
\hline UNRWA (AI Wihdat refugee camp) & 5 & 29.8 & 2.4 & 10.2 \\
\hline YWCA (AI Baqa'a refugee camp) & 4 & 30.3 & 3.0 & 3.5 \\
\hline \multicolumn{5}{|l|}{ Widowed } \\
\hline SPC (member's house) & 3 & 45.7 & 3.3 & 15.3 \\
\hline UNRWA (Jabal Hussein refugee camp) & 8 & 41.4 & 5.6 & 9.4 \\
\hline YWCA (Al Baqa'a refugee camp) & 9 & 45.9 & 6.2 & 5.4 \\
\hline
\end{tabular}

$N A=$ not available; UJ = University of Jordan Faculty of Nursing and Community Service Office; SPC = Single Parents' Club; SIGI = Sisterhood is Global Institute; UNRWA = United Nations Relief and Works Agency for Palestinian Refugees; YWCA = Young Women's Christian Association.

Wihdat refugee camp $=$ Amman new camp.

cal violence, no changes were made. For control and psychological violence, several behaviour-specific items were added. For control, not allowing dialogue or not taking the respondent's opinion, restricting the respondent's movement outside the home, and restricting visitors to the home or the respondent's ability to visit others were added to the questionnaire. For psychological violence, questions were appended by the following experiences: being accused of not fulfilling obligations toward husband and children, being blamed for events that happened in the household and being threatened with divorce or remarriage. For sexual violence, fear in relation to sexual intercourse was removed from the questionnaire because sexual violence was discussed in the focus groups in only the most extreme terms. The measurement of sexual violence was limited to forced or degrading sexual experiences.

The revised questionnaire was translated to Arabic and back-translated to English to verify that the meaning of the questions had not changed during translation. 


\section{Survey}

\section{Sample}

A representative sample of literate, evermarried (married, divorced or widowed) women attending 1 of 7 selected JAFPP reproductive health clinics was drawn using systematic probability proportionate to size methodology. Beginning with the second client on the list, every other client was invited to participate except in the 2 busiest clinic, where the interval was increased to every third or fourth client. Women accompanying the selected respondents were ineligible to participate. Overall, $517(70 \%)$ of the selected respondents agreed to participate.

A clinic-based sample was chosen because privacy could not be guaranteed in women's homes, where family members, friends and neighbours might be present. In the clinic setting, a woman could more easily be separated from those accompanying her. The recruitment process mimicked normal clinic procedures so that persons accompanying the client would not be made aware of the client's participation.

\section{Process}

The questionnaire was self-administered in private rooms in the clinics after JAFPP family planning counsellors or volunteers ascertained the client's eligibility and obtained her oral consent. To ensure confidentiality, each client was asked not to write her name on the form, and to seal the completed questionnaire in an envelope. Each participant was also offered a copy of the informed consent form and information about domestic violence services in the area.

\section{Data analysis}

The percentage of women who reported having ever experienced intimate partner violence since marriage was calculated separately for every item of the following outcomes: control, psychological violence, physical violence and sexual violence. A measure of ever-experience of any of the acts of violence since marriage was calculated for each type of violence investigated. The ever-experience measures for control and psychological violence were calculated twice: once with all the items in the outcome and once restricted to the items in the WHO questionnaire. External validity of the sample was examined by conducting univariate tests comparing the respondents' characteristics to the 2002 Demographic and Health Survey (JPFHS), which is a nationallyrepresentative sample of ever-married women of reproductive age in Jordan [18].

\section{Results}

Table 2 presents the respondents' characteristics. The mean age of the respondents was 31.4 years [standard deviation (SD) 7.8]. Almost all the women (99.0\%) were married at the time of the survey; $3.7 \%$ were in polygamous marriages. A total of $85.5 \%$ of the respondents had at least secondary education, $12.9 \%$ were employed outside the home and $97.7 \%$ were Muslim. When compared to the 2002 JPFHS, our sample was significantly younger, more likely to be married, more likely to be employed, better educated, less likely to be living in central Jordan and less likely to be in a polygamous relationship. The respondents were not statistically different, however, in terms of religion.

A total of 479 women (97.2\%) reported experiencing at least 1 form of control. When restricted to the WHO questionnaire items, this dropped to $408(82.9 \%)$. The most frequently reported form of control was the husband not accepting the respondent's opinion or allowing dialogue about family issues $(84.3 \%)$. Jealousy was the second 


\begin{tabular}{|c|c|c|}
\hline Characteristic & No. & $\%$ \\
\hline \multicolumn{3}{|l|}{$\overline{\text { Age (years) }}{ }^{\star}$} \\
\hline $15-19$ & 20 & 3.9 \\
\hline 20-24 & 98 & 19.1 \\
\hline $25-29$ & 122 & 23.8 \\
\hline 30-34 & 119 & 23.2 \\
\hline 35-39 & 84 & 16.4 \\
\hline $40-44$ & 45 & 8.8 \\
\hline $45+$ & 24 & 4.7 \\
\hline \multicolumn{3}{|l|}{ Marital status* } \\
\hline Married & 508 & 99.0 \\
\hline $\begin{array}{l}\text { Divorced/sep } \\
\text { widowed }\end{array}$ & 5 & 1.0 \\
\hline \multicolumn{3}{|c|}{ Polygamous relationship* } \\
\hline No & 490 & 96.3 \\
\hline Yes & 19 & 3.7 \\
\hline \multicolumn{3}{|c|}{ Educational level* } \\
\hline None & 2 & 0.4 \\
\hline Primary & 11 & 2.2 \\
\hline Preparatory & 61 & 12.0 \\
\hline Secondary & 248 & 48.6 \\
\hline Higher & 188 & 36.9 \\
\hline \multicolumn{3}{|c|}{ Employed outside the home* } \\
\hline No & 444 & 87.1 \\
\hline Yes & 66 & 12.9 \\
\hline \multicolumn{3}{|l|}{ Region* } \\
\hline North & 222 & 42.9 \\
\hline Central & 219 & 42.4 \\
\hline South & 76 & 14.7 \\
\hline \multicolumn{3}{|l|}{ Religion } \\
\hline Muslim & 499 & 97.7 \\
\hline Christian & 12 & 2.4 \\
\hline
\end{tabular}

${ }^{*}$ Significant difference $(P<0.05)$ compared with the 2002 Jordan Demographic and Health Survey [24]. Percentages may not add to $100 \%$ due to rounding. There are some missing values throughout.

most reported form of control (57.5\%), followed by being required to ask permission before seeking health care (53.7\%). Suspicion about the respondent's fidelity (4.2\%) and being locked in the house or having her movements outside the home curtailed $(9.1 \%)$ were the least commonly reported.
For psychological violence, 348 (73.4\%) of the respondents reported experiencing at least 1 form. When restricted to only the items included in the WHO questionnaire this dropped to 237 (50.2\%). The most prevalent experiences of psychological violence, reported by between $43.5 \%$ and $44.7 \%$ of the women, included: being blamed for things that happened to her husband or to the household, being insulted or made to feel bad and being accused of not fulfilling marital obligations towards her husband (Table 4). The least frequently reported form of psychological violence was being threatened with harm to herself or someone she cared about (7.5\%).

For physical violence, 146 (31.2\%) of the respondents reported ever-experiencing at least 1 form since marriage. The most prevalent form of physical violence was being slapped or being the target of a dangerous thrown object (23.4\%) (Table 5). The most lethal forms of violence, such as being choked or experiences involving weapons, were the least often reported forms of violence at approximately $1.0 \%$.

At least 1 of the 2 forms of sexual violence investigated was experienced by 87 (18.8\%) respondents. Being physically forced to have sexual intercourse was reported by $16.5 \%$ and being forced into degrading or humiliating sexual acts by $6.9 \%$ (Table 5).

\section{Discussion}

Our findings suggest that a large proportion of women in Jordan have experienced intimate partner violence at some point during their marriage. The proportion of respondents who reported experiencing at least one form of control or violence since marriage were: control, 97\%; psychological violence, $73 \%$; physical violence, $31 \%$; and sexual

المجلة الصحية لشرق المتو سط، منظمة الصحة العالمية، المجلد الخامس عشر، العدد ع، 9 +. 


\begin{tabular}{|c|c|c|c|}
\hline \multirow[t]{2}{*}{ Type of control } & \multicolumn{2}{|c|}{ Control experienced (\%) } & \multirow[t]{2}{*}{ Total no. } \\
\hline & Yes & No & \\
\hline $\begin{array}{l}\text { Does not allow dialogue or does not take your opinion } \\
\text { on issues that affect you or the familya }\end{array}$ & 84.3 & 15.7 & 483 \\
\hline Gets angry if you speak with another man & 57.5 & 42.5 & 485 \\
\hline $\begin{array}{l}\text { Expects you to ask his permission before seeking } \\
\text { health care for yourself }\end{array}$ & 53.7 & 46.3 & 484 \\
\hline Insists on knowing where you are at all times & 33.6 & 66.4 & 476 \\
\hline $\begin{array}{l}\text { Restricts your ability to visit others or have visitors in } \\
\text { the home }\end{array}$ & 15.0 & 85.0 & 487 \\
\hline Tries to restrict contact with your family of birth & 13.9 & 86.1 & 483 \\
\hline Ignores you and treats you indifferently & 10.4 & 89.6 & 479 \\
\hline Tries to keep you from seeing your friends & 10.4 & 89.6 & 481 \\
\hline $\begin{array}{l}\text { Restricts your movement outside the home or } \\
\text { physically locks you in the home } \\
\text { Is often suspicious that you are unfaithful }\end{array}$ & $\begin{array}{l}9.1 \\
4.2\end{array}$ & $\begin{array}{l}90.9 \\
95.8\end{array}$ & $\begin{array}{l}483 \\
479\end{array}$ \\
\hline
\end{tabular}

altems added to the WHO questionnaire from results of focus group discussions.

violence, $19 \%$. The estimates for control and psychological violence dropped to $83 \%$ and $50 \%$ respectively when the analysis was restricted to the WHO questionnaire items.
This difference in prevalence was expected given that estimates tend to increase in response to broader definitions of violence $[12,19,20]$.

Table 4 Survey participants having experienced psychological violence by type and frequency Type of psychological violence $\quad$ Psychological violence experienced (\%) $\quad$ Total no.

\begin{tabular}{|c|c|c|c|c|c|c|}
\hline & \multirow{3}{*}{ No } & \multirow{2}{*}{\multicolumn{4}{|c|}{$\begin{array}{l}\text { Yes } \\
\end{array}$}} & \\
\hline & & & & & & \\
\hline & & Ever & Once & $\begin{array}{l}\text { A few } \\
\text { times }\end{array}$ & $\begin{array}{l}\text { Many } \\
\text { times }\end{array}$ & \\
\hline $\begin{array}{l}\text { Blamed you for things that happen to } \\
\text { him or the household }\end{array}$ & 55.3 & 44.7 & 8.2 & 29.2 & 7.3 & 463 \\
\hline $\begin{array}{l}\text { Insulted you or made you feel bad } \\
\text { about yourself }\end{array}$ & 56.3 & 43.7 & 11.9 & 23.2 & 8.5 & 469 \\
\hline $\begin{array}{l}\text { Accused you of not fulfilling your } \\
\text { obligations to him }\end{array}$ & 56.5 & 43.5 & 13.6 & 25.7 & 4.3 & 464 \\
\hline $\begin{array}{l}\text { Accused you of not fulfilling your } \\
\text { obligations to your children }\end{array}$ & 75.7 & 24.3 & 6.7 & 14.7 & 2.9 & 449 \\
\hline Threatened to divorce you or remarry ${ }^{a}$ & 77.3 & 22.7 & 9.3 & 7.8 & 5.6 & 463 \\
\hline $\begin{array}{l}\text { Belittled or humiliated you in front of } \\
\text { other people }\end{array}$ & 78.0 & 22.0 & 6.7 & 11.1 & 4.1 & 460 \\
\hline $\begin{array}{l}\text { Did things to scare or intimidate you on } \\
\text { purpose (e.g. by the way he looked } \\
\text { at you, by yelling and smashing things) }\end{array}$ & 77.9 & 22.1 & 7.7 & 11.3 & 3.1 & 452 \\
\hline $\begin{array}{l}\text { Threatened to hurt you or someone you } \\
\text { care about }\end{array}$ & 92.5 & 7.5 & 3.3 & 2.7 & 1.6 & 453 \\
\hline
\end{tabular}

altems added to the WHO questionnaire from results of focus group discussions.

Percentages may not add to $100 \%$ due to rounding. 


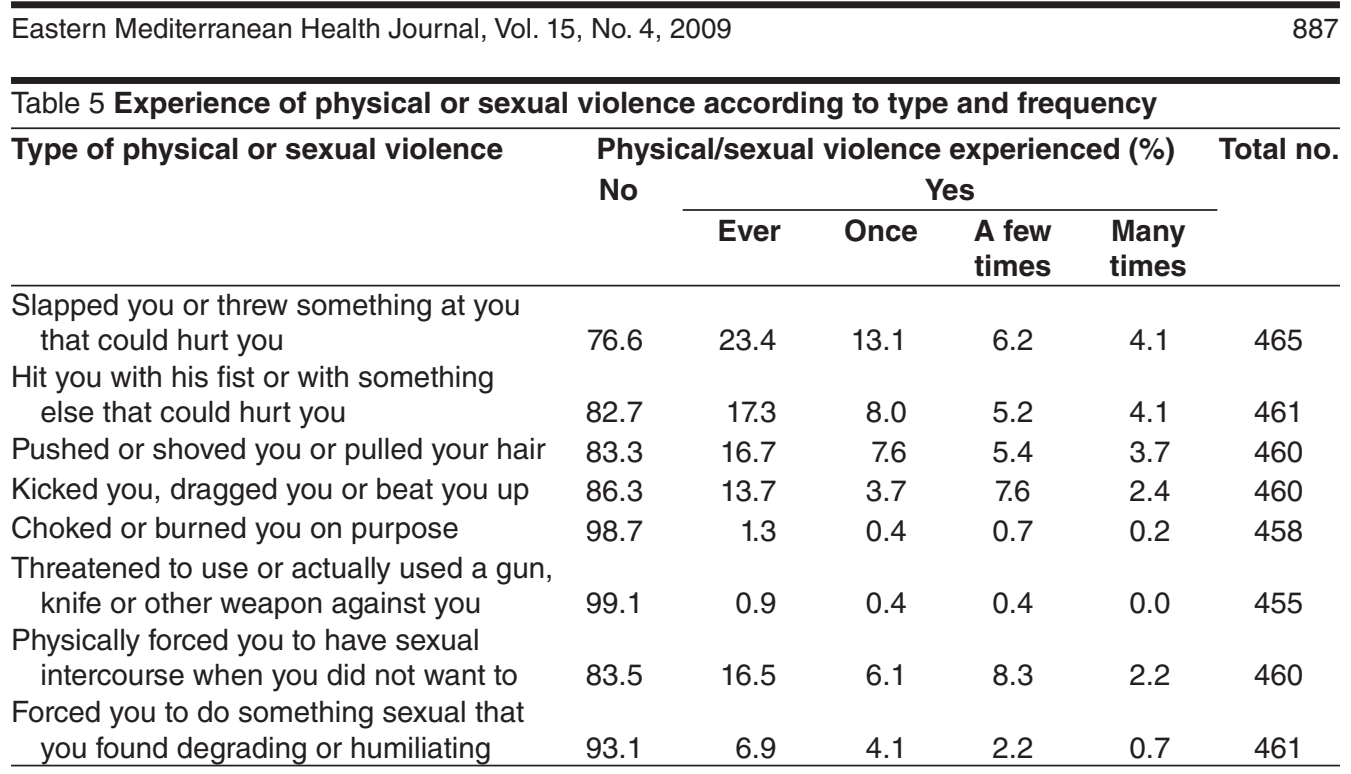

Percentages may not add to $100 \%$ due to rounding.

The study sought to balance standardization and validity through the inclusion of both quantitative and qualitative methodologies. In many instances, the focus group information confirmed the congruence between items on the WHO questionnaire and women's experiences of violence. This evidence supports calls for the use of standardized cross-cultural research on intimate partner violence $[2,21]$, particularly when it is accompanied by qualitative research. The qualitative component of the study, however, also demonstrated that additional research is needed to more accurately measure women's experiences of control and psychological violence, as these domains required considerable augmentation in the Jordanian context.

This study has several limitations. First, $30 \%$ of the women approached for the survey eventually did not participate. Secondly, the qualitative study relied on women who participated in organizations. These organizations attract diverse women to their services and activities, but, ultimately, these women's perceptions and experiences may not reflect those of women who are unable or unwilling to benefit from such organizations. Thirdly, the survey relied on women who attended one of a series of privately run reproductive health clinics. Although these clinics are located throughout the country, the respondents selected from these clinics were significantly different from a nationally representative sample of women on several demographic variables, indicating that the results cannot be extended beyond the sample. Finally, consensus on a definition of violence was not an objective of the study. Therefore, it is unclear the extent to which the items listed matched each participant's definition of violence. Further research is needed to clarify the issue.

This study, however, is the first to provide an estimate of intimate partner violence in Jordan beyond refugee camp populations. The study of refugee camp populations used an instrument similar to the WHO questionnaire to measure physical intimate partner violence and found a life-time prevalence of $42.5 \%$ [22]. The refugee camp study also included men, of whom $48.9 \%$ reported

المجلة الصحية لشرق المتوسط، منظمة الصحة العالمية، المجلد الخنامس عشر، العدد ع، 9 +. 
ever physically abusing their wives. These figures are considerably higher than those established by our study, a difference likely attributable to the added stress of refugee camp life. Refugee camp households in Jordan are larger, have higher dependency ratios, lower economic status and lower educational attainment than those not in camps [23]. The relationship between low socioeconomic status and a greater risk of intimate partner violence is well established.

The prevalence estimate of physical intimate partner violence in this study is within the range of most sites investigated in the WHO multi-country study (23\%-49\%) [1], as is the prevalence estimate for sexual violence $(10 \%-50 \%)[1]$. However, the removal of one of the sexual violence questions resulted in a narrower definition. As a result, the prevalence estimate established might be an underestimate when compared to others involving all 3 sexual violence questions.

In terms of psychological violence and control, most women experienced at least 1 form, particularly when findings from the focus group discussions were included. The additional items represent aspects of control and psychological violence that are relevant to women in Jordan but are not included in the WHO instrument. However, these experiences have salience outside the country. Two studies conducted among women in the West Bank and Gaza Strip defined psychological abuse to include several experiences similar to those added to the WHO questionnaire in this study. These items included having their husband finish an argument and make his own decision about a matter that concerns both of them, experiencing interference in doing what they wanted (the study provided the example of visiting relatives or friends) and having been accused of being lazy, indifferent and failing to fulfil her obligations to her husband and the household [10]. While these items demonstrate some similarity in abusive experiences, further research is needed to ascertain the extent to which the items added to the WHO questionnaire for this study represent major forms of suffering for women throughout the Middle East region and beyond. Furthermore, it remains to be determined whether these items also have an impact on women's health that is similar to those found with other forms of psychological violence and control $[5,24]$.

\section{References}

1. Garcia-Moreno $\mathrm{C}$ et al. WHO multi-country study on women's health and domestic violence against women: initial results on prevalence, health outcomes and women's responses. Geneva, World Health Organization, 2005.

2. Heise L, Garcia-Moreno C. Violence by intimate partners. In: Krug EG et al., eds. World report on violence and health. Geneva, World Health Organization, 2002.

3. Campbell JC. Health consequences of intimate partner violence. Lancet, 2002, 359:1331-6.
4. Golding JM. Intimate partner violence as a risk factor for mental disorders: a metaanalysis. Journal of family violence, 1999, 14:99-132.

5. Coker AL et al. Physical health consequences of physical and psychological intimate partner violence. Archives of family medicine, 2000, 9:451-7.

6. Campbell JC et al. Reproductive health consequences of intimate partner violence. A nursing research review. Clinical nursing research, 2000, 9:217-37. 
7. Sadowski LS et al. The world studies of abuse in the family environment (WorldSAFE): a model of a multi-national study of family violence. Injury control and safety promotion, 200411(2):81-90.

8. Sunita K, Johnson K. Profiling domestic violence-a multi-country study. Calverton, Maryland, ORC Macro, 2004.

9. El-Zanaty $\mathrm{FH}$ et al. Egypt demographic and health survey 1995. Calverton, MD, National Population Council and Macro International Inc, 1996.

10. Haj-Yahia MM. The incidence of wife abuse and battering and some sociodemographic correlates as revealed by two national surveys in Palestinian society. Journal of family violence, 2000, 15:34774.

11. Maziak W, Asfar T. Physical abuse in lowincome women in Aleppo, Syria. Health care women international 2003, 24:31326.

12. Schwartz MD. Methodological issues in the use of survey data for measuring and characterizing violence against women. Violence against women, 2000, 6:81538.

13. Cousineau M-M, Rondeau G. Toward a transnational and cross-cultural analysis of family violence: issues and recommendations. Violence against women, 2004, 10:935-49.

14. Glesne C. Becoming qualitative researchers: an introduction. New York, Longman, 1999.

15. Stewart DW, Shamdasani PN. Focus groups: theory and practice. Thousand Oaks, California, Sage Publications, 1990.

16. Morgan DL. Focus groups as qualitative research. Thousand Oaks, California, Sage Publications, 1997.
17. Strauss A, Corbin J. Basics of qualitative research: techniques and procedures for developing grounded theory. Thousand Oaks, California, Sage Publications, 1998.

18. Jordan population and family health survey 2002. Amman, Jordan, Department of Statistics, and Calverton, Maryland, USA, ORC Macro, 2003.

19. Smith MD. Enhancing the quality of survey data on violence against women: a feminist approach. Gender and society, 1994, 8:109-27.

20. DeKeseredy WS. Current controversies on defining nonlethal violence against women in intimate heterosexual relationships: empirical implications. Violence against women, 2000, 6:728-46.

21. Saltzman LE. Definitional and methodological issues related to transnational research on intimate partner violence. Violence against women, 2004, 10:812-30.

22. Khawaja M, Barazi R. Prevalence of wife beating in Jordanian refugee camps: reports by men and women. Journal of epidemiology and community health, 2005, 59:840-1.

23. Khawaja M, Tiltnes AA, eds. On the margins: migration and living conditions of Palestinian camp refugees in Jordan. Fafo-report No. 357. Oslo Norway, Fafo Research Foundation, 2002:210 (http:// www.fafo.no/pub/rapp/357/index.htm, accessed 18 December 2008).

24. Bonomi $A E$ et al. Intimate partner violence and women's physical, mental, and social functioning. American journal of preventive medicine, 2006, 30:458-66. 